Special issue of the 3rd International Conference on Computational and Experimental Science and Engineering (ICCESEN 2016)

\title{
Pollution Determined by Using Magnetic Susceptibility Measurements: A Case Study from İzmir-Aliağa
}

\author{
Z. $\mathrm{KAMACI}^{a, *}$ AND G. UYSAL ${ }^{b}$ \\ ${ }^{a}$ Süleyman Demirel University, Faculty of Engineering, Isparta, Turkey \\ ${ }^{b}$ Süleyman Demirel University, Graduate School of Applied and Natural Sciences, Isparta, Turkey \\ Wherever industrial development exists, environmental pollution increases day by day. The heavy metals play \\ an important role in soil and environmental pollutions and directly affect the human being lives. In this study, \\ we determine pollutions resulting from heavy metal particles emanating from the brake discs pads of the vehicles \\ on high ways and nearby factories. The field work was carried out in İzmir-Aliağa industrial area. Magnetic \\ susceptibility measurements were done at a long profile crossing the İzmir-Çanakkale highway that goes through \\ the study area. Here, we have determined the effect of heavy metals causing pollution in the surroundings. The \\ studies indicate that the average acceptable values of magnetic susceptibility in such areas is about $0-50 \times 10^{-5}$ SI. \\ Here we show that the magnetic susceptibility measurement values obtained along our study profile are about 18 \\ times the acceptable ranges.
}

DOI: 10.12693/APhysPolA.132.487

PACS/topics: environmental geophysics, pollution, magnetic susceptibility

\section{Introduction}

Environmental pollution is a threat to humanity and is an important problem to be tackled. Heavy metals emanating to the sky as a result of industrial activity, eventually reach the soil and consequently the plants, and through the food chain the animals and the human beings [1]. The density of the vehicles in the traffic, rising as a result of increase in the population, is another factor that causes environmental pollution.

On the other hand, considerable amount of pollution emerge as soil contamination by heavy metal particles emanating from the friction of the break discs of the vehicles travelling on the highway. The studies carried out by the researchers [2-19] show that the pollution level caused by urban and industrial wastes containing heavy metals can be detected by magnetic susceptibility (MS) measurements. The studies of [20-24] claim that the emission from the vehicles are strong magnetic polluters and point out the importance of the MS measurements.

The aim of this study is to determine the environmental pollution level caused by the heavy metal particles in the industrial wastes and emanating from the vehicles, using one of the exploration geophysics tools, namely the MS method. The usage of the MS parameter in the soil pollution analysis emerge from the anomaly resulting from the heavy metals contaminating the soil. As such, the measurements in this study were done using the Bartington MS2E instrument along a profile crossing perpendicularly the İzmir-Çanakkale highway in İzmirAliağa industrial area where several polluters exist. Although the average expected MS values are in the range

*corresponding author; e-mail: zuheyrkamaci@gmail.com of $0-50 \times 10^{-5}$ SI the measurements revealed values 18 times higher than the expectations.

\subsection{The location and surface geology of the study area}

The Aliağa (İzmir-Turkey) study area is located in Western Anatolia, $50 \mathrm{~km}$ away from İzmir (Fig. 1). The following geologic features occur in the area: pliocene bazaltic volcanic rocks and upper miocene limestone, silicon limestone, marn, andesite, tuff, and volcanicsedimentary.

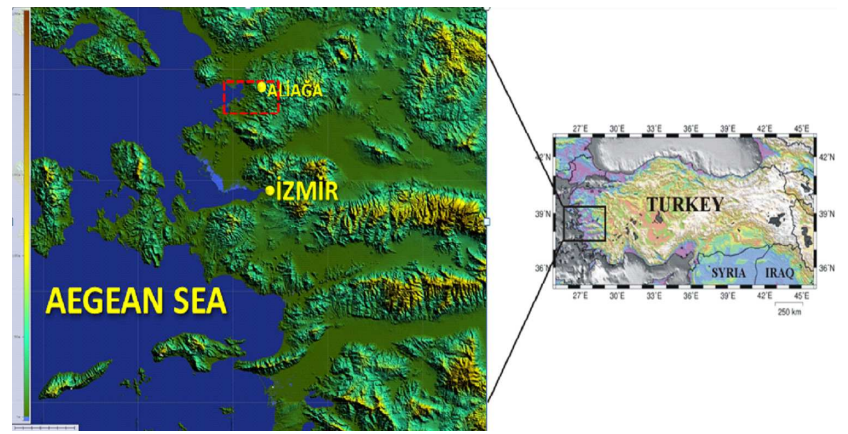

Fig. 1. Location of study area.

\subsection{Chemical analysis of soil samples}

Table I shows the chemical analysis results of soil samples acquired from İzmir-Aliağa region in 1992 [25] and 1997 [26] with an aim to determine the heavy metal concentration such as $\mathrm{Fe}, \mathrm{Ti}, \mathrm{Mn}, \mathrm{Cr}, \mathrm{Ni}, \mathrm{Cu}, \mathrm{Pb}, \mathrm{Zn}$, and Mo. According to these results, the heavy metals in the soil samples are mostly acquired from sites nearby the industrial facilities. Similarly, the air quality is found to be poor in those regions. Moreover, these studies show that the heavy metal concentration significantly decreases at location away from the industrial facilities. 
TABLE I

Chemical analysis results in soil samples from the study area in 1992 [25] and 1997 [26].

\begin{tabular}{|c|c|c|c|c|c|c|c|c|c|c|c|}
\hline \multirow[t]{2}{*}{ Sample } & \multirow{2}{*}{$\begin{array}{c}\text { Distance } \\
{[\mathrm{m}]}\end{array}$} & \multirow{2}{*}{$\begin{array}{l}\text { Depth } \\
{[\mathrm{cm}]}\end{array}$} & $\mathrm{Fe}$ & $\mathrm{Ti}$ & $\mathrm{Mn}$ & $\mathrm{Cr}$ & $\mathrm{Pb}$ & $\mathrm{Cu}$ & $\mathrm{Ni}$ & $\mathrm{Zn}$ & Mo \\
\hline & & & \multicolumn{2}{|c|}{ [\%] } & \multicolumn{7}{|c|}{ [ppm] } \\
\hline NT6 (1992) & 250 & $0-5$ & 1.6 & - & 758 & 3.7 & 61 & - & 22 & 215 & - \\
\hline \multirow{2}{*}{ NT2 } & \multirow{2}{*}{750} & $0-5$ & 4.2 & - & 486 & 6.4 & 22 & - & 23 & 243 & - \\
\hline & & $5-15$ & 5.54 & - & 580 & 4.3 & 12 & - & 24 & 123 & - \\
\hline \multirow{2}{*}{ NT3 } & \multirow{2}{*}{1500} & $0-5$ & 4.19 & - & 1155 & 4.7 & 17 & - & 23 & 48 & - \\
\hline & & $5-15$ & 3.9 & - & 1065 & 4.5 & 21 & - & 23 & 17 & - \\
\hline \multirow{2}{*}{ NT4 (1997) } & \multirow{2}{*}{50} & $0-5$ & 4.0 & 1.7 & 6932 & 538 & 603 & 116 & 70 & 3016 & \\
\hline & & $5-15$ & 3.65 & 0.7 & 6000 & 359 & 503 & 98 & 56 & 2890 & 0 \\
\hline \multirow{2}{*}{$\mathrm{T} 2$} & \multirow{2}{*}{150} & $0-5$ & 2.8 & 2.5 & 852 & 137 & 112 & 32 & 85 & 317 & 0 \\
\hline & & $5-15$ & 2.0 & 2.0 & 780 & 98 & 98 & 23 & 60 & 230 & 0 \\
\hline \multirow{2}{*}{ NT6 } & \multirow{2}{*}{250} & $0-5$ & 1.8 & 1.3 & 1077 & 42 & 112 & 23 & 50 & 155 & 0 \\
\hline & & $5-15$ & 1.4 & 0.7 & 865 & 23 & 100 & 20 & 42 & 134 & \\
\hline \multirow{2}{*}{$\mathrm{T} 1$} & \multirow{2}{*}{350} & $0-5$ & 1.4 & 0.8 & 601 & 19 & 80 & 32 & 35 & 159 & 0 \\
\hline & & $5-15$ & 0.8 & 0.3 & 678 & 9 & 69 & 30 & 31 & 123 & \\
\hline \multirow{2}{*}{ NT1 } & \multirow{2}{*}{500} & $0-5$ & 3.2 & 2.5 & 402 & 118 & 80 & 54 & 90 & 181 & 0 \\
\hline & & $5-15$ & 1.9 & 2.0 & 423 & 89 & 45 & 41 & 82 & 174 & \\
\hline \multirow{2}{*}{ NT5 } & \multirow{2}{*}{600} & $0-5$ & 1.2 & 0.8 & 786 & 31 & 86 & 19 & 45 & 71 & 0 \\
\hline & & $5-15$ & 0.6 & 0.3 & 569 & 30 & 76 & 12 & 23 & 45 & 0 \\
\hline \multirow{2}{*}{ NT2 } & \multirow{2}{*}{750} & $0-5$ & 3 & 1.5 & 865 & 126 & 202 & 45 & 100 & 706 & 0 \\
\hline & & $5-15$ & 1.4 & 1.2 & 789 & 100 & 160 & 36 & 81 & 390 & 0 \\
\hline \multirow{2}{*}{ NT3 } & \multirow{2}{*}{1500} & $0-5$ & 2.8 & 1.5 & 850 & 80 & 139 & 43 & 80 & 142 & 0 \\
\hline & & $5-15$ & 0.5 & 0.4 & 803 & 56 & 100 & 29 & 60 & 129 & 0 \\
\hline
\end{tabular}

\subsection{Field work}

MS measurements were taken using Bartington MS2E sensor along a $700 \mathrm{~m}$ long profile crossing perpendicularly the İzmir-Çanakkale highway passing by the Çebitaş, Özkan and Habaş iron and steel facilities (Fig. 2).

Figure 3 portrays the profiles where the MS data were acquired.

According to the analysis results of the profile; the asphalt and the soil are polluted by the metallic dust carried by winds from the industrial facilities and by the metallic particles emanating from the metal discs friction resulting from frequent breaking of the vehicles travelling on İzmir-Aliağa highway. The MS values along the profile reach an average of 900 at locations where the pollution is high. This in turn indicates the sites where the metal pollution is high in the soil and asphalt. Moreover, because of the wind effects the MS values between 50 and 200 are observed at SW side of the profile where the facilities are located. Similarly, the MS values around 50 are observed at NE side of the profile at locations away from the industrial facilities indicating lower pollution levels in the soil and asphalt.

\section{Conclusions}

The MS measurements along a profile crossing the İzmir-Çanakkale highway that passes by Aliağa region, yield that the heavy metal pollutions causes MS anomaly. The anomaly is drawn by estimating the average of three values measured at each observation point. The results

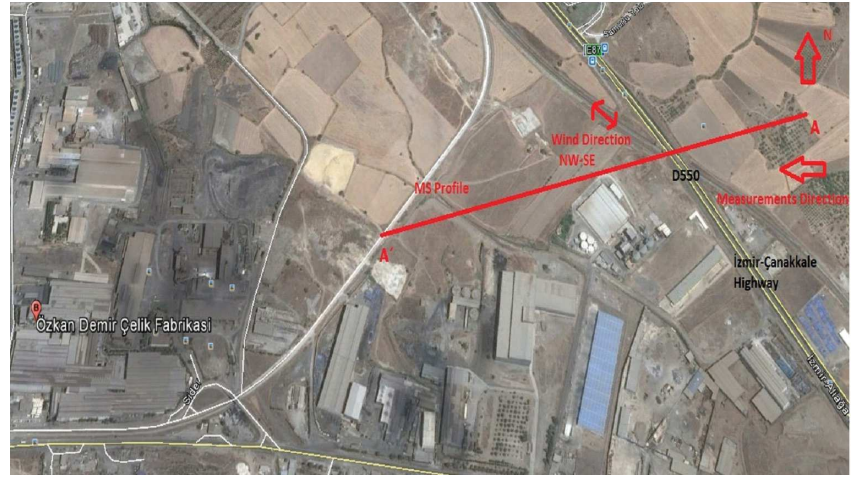

Fig. 2. A satellite image of the location of the MS profile in İzmir-Aliağa industrial region.

point out a pollution level that is 18 times higher than the normal values. This in turn indicates that in the regions where İzmir-Çanakkale highway and the iron-steel industrial facilities are located, the heavy metal pollution is extremely high. The direction of the wind is also effective in the spatial distribution of the pollution. This is based on the fact that the spatial elongation of the pollution is in line with the general trend of the wind. In this respect, it is noteworthy to state that the nearby agricultural areas which are in line with the wind direction are subject to pollution resulting from the polluted dust emanating from the chimneys of the iron-steel factories and from the garbage waste storage areas. 


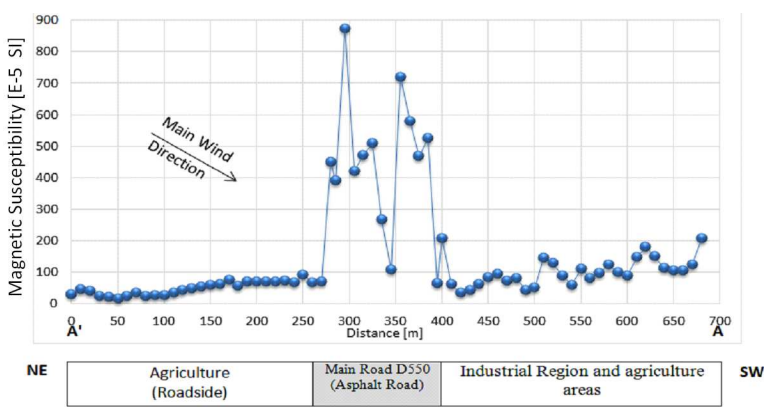

Fig. 3. Profile of the magnetic susceptibility across İzmir-Çanakkale highway D550 (traffic density about 15,000 vehicles per day).

\section{Acknowledgments}

We are grateful to the Administration of the SDU Scientific Research Project Unit that financially supported this study under the project contract No. 3662-YL1-13. In addition, we thanks Prof. Dr. Coşkun Sarıand Assistant Prof. Dr. Emre Timur for their support during the field work.

\section{References}

[1] Ö. Kahvecioğlu, G. Kartal, A. Güven, S. Timur, Metallerin Çevresel Etkileri İstanbul Teknik Üniversitesi Metalurji ve Malzeme Mühendisliği, 2001.

[2] G. Ising, Appl. Math. Astron. Phys. 29A, 1 (1943).

[3] E. Le Borgne, Ann. Geophys. 11, 399 (1955).

[4] C.E. Mullins, M.S. Tite, J. Geophys. Res. 78, 804 (1973).

[5] M.S. Tite, R.E. Linington, Nature 256, 565 (1975).

[6] C.E. Mullins, J. Soil Sci. 28, 223 (1977).

[7] M. Scoullos, F. Oldfield, R. Thompson, Marine Pollut. Bull. 10, 287 (1979).

[8] R. Thompson, F. Oldfield, Environmental Magnetism, Allen and Unwin, London 1986.
[9] J. Dearing, Environmental Magnetic Susceptibility, Bartington Instruments, Witney, Oxon, England 1994.

[10] P.J. Flanders, J. Appl. Phys. 75, 5931 (1994).

[11] K.L. Verosub, A.P. Roberts, J. Geophys. Res. 100, 2175 (1995).

[12] A. Aydın, K. Gelişli, Jeofizik 10, 40 (1996) (in Turkish).

[13] K. Gelişli, A. Aydın, D. Dondurur, S. Livaoğlu, Manyetik Duyarlılık Ölçümleri İle Yeniay-Çamburnu (Trabzon) Bölgesinin Kirlilik Etüdü, 1996.

[14] K. Gelişli, A. Aydın, Europ. J. Environm. Eng. Geophys. 3, 53 (1998).

[15] V. Hoffmann, M. Knab, E. Appel, J. Geochem. Explor. 66, 313 (1999).

[16] D. Kale, Aliağa (İzmir) Endüstri Bölgesinde Topraktaki Ağır Metal Kirliliğinin Manyetik Duyarlılık Ölçümleri İle Belirlenmesi, Dokuz Eylül Üniversitesi Fen Bilimleri Enstitüsü, Yüksek Lisans Tezi, İzmir 2014.

[17] D. Kale, C. Sarı, in: 8th Congress of the Balkan Geophysical Society, Chania, Crete (Greece), 2015.

[18] E. Timur, Environm. Earth Sci. 72, 2497 (2014).

[19] M. Canbay, A. Aydın, C. Kurtulus, J. Appl. Geophys. 70, 46 (2010).

[20] A. Hunt, Phys. Earth Planet. Inter. 42, 10 (1986).

[21] Z. Strzyszcz, in: Soils Monitoring, Birkhäuser Verlag, Basel 1993, p. 225.

[22] Z. Strzyszcz, T. Magiera, Phys. Chem. Earth 23 , 1127-1131 (1998).

[23] O. Durza, Phys. Chem. Earth 24, 541 (1999).

[24] A. Kapicka, E. Petrovsky, K. Machackova, S. Ustjak, Ann. Geophys. 15, C103, Suppl. (1999).

[25] E. Henden, I. Türkan, S. Kıvılcım, U. Çelik, Environm. Res. Forum 7-8, 292 (1997).

[26] D. Sponza, N. Karaoğlu, Environm. Int. 27, 541 (2002). 